\title{
Hubungan Indeks Massa Tubuh dan Lama Penyemprotan dengan Diabetes Mellitus pada Petani di Desa Juhar Ginting Sadanioga Kabupaten Karo Tahun 2018
}

\author{
Naysya Vitianoza ${ }^{1}$, Nurmaini Nurmaini ${ }^{2}$, Taufik Ashar ${ }^{3}$ \\ Fakultas Kesehatan Masyarakat Universitas Sumatera Utara, J1. Universitas No. 21 Kampus \\ USU, Medan 20155, Indonesia \\ naysya.vitacham@gmail.com,${ }^{2}$ nurmaini@usu.ac.id,, doctta@gmail.com
}

\begin{abstract}
Abstrak
Diabetes mellitus merupakan penyakit tidak menular (Non Comunicable Disease) yang cukup banyak diderita oleh masyarakat di dunia dan Indonesia. Penderita kasus baru diabetes mellitus di Desa Juhar Ginting Sadanioga pada bulan Februari 2018 adalah 195 kasus. Penggunaan pestisida dengan dosis tinggi dan dalam jangka panjang dapat menimbulkan dampak negatif bagi masyarakat. Penelitian ini bertujuan untuk mengetahui hubungan indeks massa tubuh dan lama penyemprotan dengan kejadian diabetes mellitus pada petani. Penelitian ini menggunakan desain cross sectional dengan jumlah sampel 60 orang petani penyemprot di Desa Juhar Ginting Sadanioga dengan teknik simple random sampling. Data dikumpulkan dengan pemeriksaan kadar gula darah, pengukuran berat badan, dan wawancara menggunakan kuesioner. Hasil menunjukkan bahwa ada hubungan IMT dengan Diabetes Mellitus ( $\mathrm{p}=0,024)$ dan ada hubungan lama penyemprotan dengan diabetes mellitus $(\mathrm{p}=0,023)$. Dari dua variabel tersebut, variabel lama penyemprotan merupakan variabel yang paling berhubungan dengan diabetes mellitus yaitu nilai RP sebesar 8,800. Kepada petani diharapkan untuk mengontrol berat badan dan melakukan penyemprotan tidak lebih dari 3 jam per hari untuk meminimalisir risiko diabetes mellitus.
\end{abstract}

Kata kunci: Indeks Massa Tubuh, Lama Penyemprotan, Pestisida, Diabetes Mellitus

\begin{abstract}
Diabetes mellitus is a non-communicable disease (Non-Communicable Disease) which quite a lot affects people in the world and Indonesia. There were 195 new cases of diabetes mellitus in Juhar Ginting Sadanioga Village in February 2018. The use of pesticides in high doses and in the long term can have negative impacts on society. This study aims to determine the relationship between body mass index and spraying time with the incidence of diabetes mellitus in farmers. This study used a cross sectional design with a total sample of 60 spraying farmers in Juhar Ginting Sadanioga Village with simple random sampling technique. Data were collected by checking blood sugar levels, measuring body weight, and interview using a questionnaire. The results showed that there was a relationship between BMI and Diabetes Mellitus $(\mathrm{p}=0.024)$ and there was a relationship between spraying time and diabetes mellitus $(p=0.023)$. Of the two variables, the spraying duration variable was the variable most associated with diabetes mellitus, namely the RP value of 8,800 . Farmers are expected to control their body weight and spray no more than 3 hours per day to minimize the risk of diabetes mellitus.
\end{abstract}

Keywords: Body Massa Index, Spraying Time, Peticide, Diabetes Mellitus

\section{Pendahuluan}

Diabetes mellitus merupakan penyakit tidak menular (Non Comunicable Disease) yang cukup banyak diderita oleh masyarakat di dunia, kasusnya semakin meningkat setiap tahun dan 
masih menjadi permasalahan kesehatan di Indonesia. Diabetes mellitus adalah penyakit kronis yang terjadi ketika pankreas tidak menghasilkan cukup insulin atau ketika tubuh tidak dapat secara efektif menggunakan insulin yang dihasilkan oleh pankreas. Insulin adalah hormon yang mengatur kadar gula darah. Hiperglikemia atau peningkatan gula darah merupakan efek yang umum dari diabetes yang tidak terkontrol dan dari waktu ke waktu menyebabkan kerusakan serius pada banyak sistem tubuh, terutama saraf dan pembuluh darah (WHO, 2017).

Menurut WHO (2017), penyakit diabetes mellitus menempati urutan keenam di dunia yang menyebabkan kematian. Jumlah penderita diabetes telah meningkat dari waktu ke waktu. Pada tahun 2013, sekitar 150 juta orang di dunia telah menderita diabetes mellitus. Pada tahun 2014, jumlah penderita diabetes mellitus 422 juta di dunia. Pada tahun 2015, diabetes adalah penyebab langsung dari 1,6 juta kematian.

Menurut Riskesdas (2013), perkiraan jumlah penderita diabetes pada usia $\geq 15$ tahun adalah 12.191.564 orang atau sekitar $6,9 \%$ dari jumlah penduduk yang berusia $\geq 15$ tahun. Proporsi penderita diabetes mellitus pada riskesdas tahun 2013 meningkat hampir dua kali lipat dibandingkan tahun 2007 (Pusdatin Kemenkes, 2014). Selain itu, menurut Riskesdas (2013), proporsi penderita diabetes mellitus pada petani/buruh adalah 6,20\% dan proporsi kadar gula darah puasa terganggu (GDP terganggu) tertinggi adalah pada petani/buruh yaitu $41,1 \%$. Prevalensi diabetes mellitus di Sumatera Utara cukup tinggi. Hal ini sesuai dengan hasil Riskesdas tahun 2013 yang menunjukkan bahwa prevalensi diabetes mellitus di Sumatera Utara pada umur lebih dari 15 tahun adalah 2,3\%. Berdasarkan data dari Laporan Bulanan Puskesmas Juhar diketahui bahwa pada tahun 2017 diabetes mellitus merupakan peringkat ke-7 dari 10 daftar penyakit tertinggi di Puskesmas Juhar dengan jumlah kasus sebesar 105 kasus. Pada bulan Februari 2018 penderita kasus baru diabetes mellitus bertambah 90 kasus sehingga jumlah kasus meningkat menjadi 195 kasus.

Diabetes mellitus memiliki patogenesis multifaktorial diantaranya komponen genetik yang kuat, pengaruh lingkungan, obesitas, dan gaya hidup. Prevalensi diabetes mellitus berbanding lurus dengan tingkat obesitas. Semakin tinggi tingkat obesitas maka semakin tinggi pula prevalensi diabetes mellitus. Selain itu, pada penelitian Trisnawati dan Setyorogo (2013) ditemukan bahwa indeks massa tubuh memiliki hubungan yang bermakna dengan kejadian diabetes mellitus. Menurut Hu et.al (2004), terdapat hubungan positif antara indeks massa tubuh dengan diabetes tipe 2 secara konsisten.

Menurut Peraturan Menteri Pertanian No.7 Tahun 2007, pestisida adalah semua zat kimia atau bahan lain serta jasad renik dan virus yang digunakan untuk tujuan memberantas atau mencegah hama dan penyakit yang merusak tanaman, bagian tanaman, atau hasil-hasil pertanian, memberantas rerumputan, mematikan daun dan mencegah pertumbuhan yang tidak diinginkan, mengatur atau merangsang pertumbuhan tanaman atau bagian-bagian tanaman (tetapi tidak termasuk dalam golongan pupuk). Dampak pestisida terhadap kesehatan sangat beragam tergantung pada golongan pestisida, intensitas pemaparan, jalan masuk dan bentuk sediaan pestisida. Selain itu, penggunaan pestisida yang tidak sesuai dengan standar keamanan dapat menimbulkan keracunan pada petani. Keracunan pestisida bermacammacam yaitu bersifat akut maupun kronis dengan variasi dampak yang dapat ditimbulkannya. Keracunan pestisida dapat ditemukan dalam tubuh manusia melalui pemeriksaan kadar kolinesterase dalam darah (Saputri dkk, 2018). 
Dampak kronis keracunan pestisida dapat berupa gangguan keseimbangan kadar glukosa darah. Menurut Rahimi dkk (2007), organofosfat dapat mempengaruhi homeostasis glukosa tubuh dengan beberapa mekanisme termasuk stres fisiologis, stres oksidatif, penghambatan paraoxonase, stres nitrosative, pankreatitis, penghambatan cholinesterase, stimulasi kelenjar adrenal, dan gangguan dalam metabolisme tryptophan hati. Paparan pestisida sebagai situasi stres yang mengancam homeostasis menyebabkan perubahan pada sumbu pertahanan tubuh seperti sistem imun-neuroendokrin dan sistem saraf otonom yang mendukung hiperglikemia (Mostafalou et.al, 2011; Mostafalou and Mohammad, 2012). Tujuan penelitian ini adalah untuk menganalisis hubungan indeks massa tubuh dan lama penyemprotan dengan diabetes mellitus pada petani.

\section{Metode}

Penelitian ini menggunakan desain cross sectional. Sampel dalam penelitian ini adalah 60 orang petani penyemprot di Desa Juhar Ginting Sadanioga dengan teknik simple random sampling. Variabel independen penelitian ini adalah indeks massa tubuh (IMT) dan lama penyemprotan. Variabel dependen penelitian ini adalah diabetes mellitus. Data dikumpulkan dengan pemeriksaan kadar gula darah, pengukuran berat badan, dan wawancara menggunakan kuesioner. Data dianalisis menggunakan uji chi-square dengan $\alpha=5 \%$ untuk analisis bivariat dan data dianalisis menggunakan uji regresi logistik untuk analisis multivariat.

\section{Hasil Dan Pembahasan}

Hasil analisis statistik indeks massa tubuh dan lama penyemprotan dapat dilihat secara rinci dalam tabel analisis beikut ini:

Tabel 1. Distribusi fekuensi indeks massa tubuh, lama penyemprotan, dan diabetes mellitus pada petani di Desa Juhar Ginting Sadanioga Kabupaten Karo

\begin{tabular}{lrr}
\hline \multicolumn{1}{c}{ Variabel } & $\mathrm{n}$ & \multicolumn{2}{c}{$\%$} \\
\hline Indeks Massa Tubuh & & \\
Berlebih & 16 & 26.7 \\
Normal & 44 & 73.3 \\
\hline Total & 60 & 100.0 \\
\hline Lama Penyemprotan & & 10.0 \\
$\geq 8$ jam/hari & 6 & 90.0 \\
\hline 8 jam/hari & 54 & 100.0 \\
\hline Total & 60 & \\
\hline Diabetes Mellitus & & 23.3 \\
$\geq 200 \mathrm{mg} / \mathrm{dL}$ & 14 & 76.7 \\
\hline $200 \mathrm{mg} / \mathrm{dL}$ & 46 & 100.0 \\
\hline Total & 60 & \\
\hline
\end{tabular}


Berdasarkan tabel 1, pada variabel indeks massa tubuh diketahui bahwa sebagian besar petani memiliki indeks massa tubuh normal yaitu 44 orang $(73,3 \%)$. Pada variabel lama penyemprotan diketahui bahwa pada umumnya petani menyemprot $<8$ jam/hari yaitu 54 orang $(90,0 \%)$. Pada variabel diabetes mellitus diketahui bahwa sebagian besar kadar gula darah petani $<200 \mathrm{mg} / \mathrm{dL}$ yaitu 46 orang $(76,7 \%)$.

Tabel 2. Hubungan Indeks Massa Tubuh dan Lama Penyemprotan dengan Diabetes pada Petani di Desa Juhar Ginting Sadanioga Kabupaten Karo

\begin{tabular}{|c|c|c|c|}
\hline \multirow{2}{*}{ Variabel } & \multicolumn{2}{|l|}{ Diabetes Mellitus } & \multirow{2}{*}{ Nilai $p$} \\
\hline & $\geq 200 \mathrm{mg} / \mathrm{dL}$ & $<200 \mathrm{mg} / \mathrm{dL}$ & \\
\hline \multicolumn{4}{|l|}{ Indeks Massa Tubuh } \\
\hline Berlebih & 7 & 9 & \multirow{2}{*}{0,024} \\
\hline Normal & 7 & 37 & \\
\hline Total & 14 & 46 & \\
\hline \multicolumn{4}{|l|}{ Lama Penyemprotan } \\
\hline$\geq 8$ jam/hari & 4 & 2 & \multirow{2}{*}{0.023} \\
\hline$<8 \mathrm{jam} / \mathrm{hari}$ & 10 & 44 & \\
\hline Total & 14 & 46 & \\
\hline
\end{tabular}

Berdasarkan tabel 2, diketahui bahwa sebagian besar responden memiliki berat badan normal dan memiliki kadar gula darah $<200 \mathrm{mg} / \mathrm{dL}$ yaitu 37 orang. Berdasarkan hasil analisis diperoleh nilai $\mathrm{p}=0,024(\mathrm{p}<0,05)$ sehingga dapat disimpulkan bahwa indeks massa tubuh (IMT) berhubungan dengan diabetes mellitus.

Hasil penelitian ini sesuai dengan hasil penelitian Trisnawati dan Setyorogo (2013) yang menyatakan bahwa IMT berhubungan dengan diabetes mellitus dan kelompok dengan risiko diabetes terbesar adalah kelompok obesitas artinya orang yang obesitas berisiko 7,14 kali lebih besar dibandingkan dengan orang yang memiliki IMT normal. Dalam penelitian AlOthman et.al (2015) dinyatakan bahwa IMT berhubungan secara signifikan dengan diabetes mellitus. Peningkatan IMT secara umum berhubungan dengan peningkatan prevalens diabetes mellitus secara signifikan. Prevalens diabetes mellitus paling tinggi terjadi pada kelompok obesitas (BMI $\geq 40 \mathrm{~kg} / \mathrm{m}^{2}$ ) (Bays et.al., 2007).

Menurut D'adamo dalam Adnan (2013) orang yang mengalami kelebihan berat badan, kadar leptin dalam tubuhnya akan meningkat. Leptin adalah hormon yang berhubungan dengan gen obesitas. Leptin berperan dalam hipotalamus untuk mengatur tingkat lemak tubuh, kemampuan untuk membakar lemak menjadi energi, dan rasa kenyang. Kadar leptin dalam plasma meningkat dengan meningkatnya berat badan. Leptin bekerja pada sistem saraf perifer dan pusat. Peran leptin terhadap terjadinya resistensi yaitu leptin menghambat fosforilasi insulin receptor substrate-1 (IRS) yang akibatnya dapat menghambat pengambilan glukosa sehingga mengalami peningkatan kadar gula dalam darah.

Selanjutnya, untuk veriabel lama penyemprotan diketahui bahwa sebagian besar responden lama penyemprotan $<8 \mathrm{jam} / \mathrm{hari}$ dan memiliki kadar gula darah $<200 \mathrm{mg} / \mathrm{dL}$ yaitu 44 orang. Berdasarkan hasil analisis diperoleh nilai $p=0,023(p<0,05)$ sehingga dapat disimpulkan bahwa lama penyemprotan berhubungan dengan diabetes mellitus. 
Lama penyemprotan merupakan lama waktu petani menyemprotan tanaman menggunakan pestisida dalam satu hari. Lama penyemprotan menunjukkan tingkat paparan pestisida terhadap petani. Semakin lama waktu yang dihabiskan petani untuk menyemprot menunjukkan semakin tinggi tingkat paparan pestisida. Seseorang tidak boleh melakukan penyemprotan lebih dari 2 jam setiap hari karena semakin lama melakukan penyemprotan maka akan semakin tinggi intensitas pemaparan yang terjadi. Kejadian diabetes pada petani Thailand berhubungan dengan paparan pestisida. (Juntarawijit and Yuwayong, 2018). Tabel 3. Hasil Analisis Multivariat dengan Menggunakan Uji Regresi Logistik.

\begin{tabular}{|c|c|c|c|}
\hline Variabel & B & Nilai $p$ & Exp.B \\
\hline IMT & 1.099 & 0.115 & 3.000 \\
\hline Lama Penyemprotan & 2.175 & 0.020 & 8.800 \\
\hline Constant & -1.482 & 0.000 & 0.227 \\
\hline
\end{tabular}

Berdasarkan tabel 3, diketahui bahwa variabel lama penyemprotan merupakan variabel independen yang paling berhubungan dengan diabetes mellitus karena memiliki nilai $\mathrm{p}=0.02$ $(\mathrm{p}<0,05)$ dengan nilai RP sebesar 8,800. Maksudnya adalah risiko terjadinya Diabetes Mellitus pada subjek yang melakukan penyemprotan $\geq 8$ jam/hari adalah 8,800 kali lebih besar dibandingkan dengan subjek yang melakukan penyemprotan $<8$ jam/hari.

Apabila petani melakukan penyemprotan melebihi batas waktu aman maka dalam jangka panjang dapat berdampak pada diabetes mellitus. Jika lama penyemprotan petani masih dalam batas waktu aman yaitu 1-3 jam, maka keracunan akibat pestisida masih dapat dikurangi. Biasanya, gejala keracunan pestisida muncul setelah 4 jam terpapar, tetapi dapat muncul pula setelah 12 jam paparan. Semakin lama petani terpapar dengan pestisida maka akan semakin besar pula risiko petani mengalami keracunan.

Sebagian besar petani melakukan penyemprotan $<8$ jam/hari, akan tetapi sebagian besar petani sudah melakukan penyemprotan lebih dari 20 tahun. Hal ini tentunya menjadi salah satu faktor lain yang harus diperhatikan mengingat waktu paparan yang sudah berlangsung menahun. Semakin lama petani kontak dengan pestisida maka semakin banyak pestisida yang masuk dan terakumulasi dalam tubuh sehingga berisiko menyebabkan gangguan kesehatan.

Selain dampak dalam jangka panjang, lama penyemprotan juga dapat menimbulkan dampak jangka pendek yaitu kadar kolinesterase dalam darah sebagai indikator keracunan pestisida dalam tubuh. Semakin lama waktu yang digunakan petani untuk sekali penyemprotan maka semakin rendah kadar kolinesterase petani. Kadar inilah yang nantinya dapat mempengaruhi kerja pankreas dalam mengatur kadar gula darah. Organofosfat bersifat toksik karena menghambat enzim asetilkolinesterase. Penghambatan enzim ini mengahasilkan asetilkolin terakumulasi di jaringan saraf dan organ efektor (Hodgson, 2004).

Kolinesterase adalah suatu enzim yang terdapat pada cairan seluller yang berfungsi menghentikan aksi asetilkolin dengan jalan terhidrolisis menjadi cholin dan asam asetat. Asetilkolin terdapat di ujung saraf dan serabut saraf. Asetilkolin merupakan materi kimia yang berfungsi untuk meneruskan impuls ke reseptor sel-sel organ termasuk pankreas. Pada 
saat pestisida masuk ke dalam darah, pestisida bertemu dengan kolinesterase dan kolinesterase akan berikatan dengan organofosfat. Ketika organofosfat berikatan dengan kolinesterase, organofosfat menghambat kerja enzim kolinesterase. Apabila kerja enzim kolinesterase terganggu, maka kerja asetilkolin juga terganggu.

Turner dan Joseph (1988) menjelaskan bahwa asetilkolin yang terdapat di sel-sel saraf pankreas berfungsi sebagai transmitter parasimpatik dalam melepaskan insulin dari sel $\beta$ secara in vivo dan in vitro. Insulin merupakan hormon yang disekresikan oleh sel $\beta$ pankreas yang berfungsi untuk menurunkan glukosa darah, memudahkan penggunaan glukosa oleh sel dan mencegah pemecahan glikogen secara berlebihan (glikogenolisis) yang disimpan dalam hati dan otot. Selain itu, insulin juga berfungsi untuk mempermudah pergerakan asam amino ke dalam sel menggiatkan imbangan nitrogen yang positif, mempermudah sintesis protein dan lemak, dan menurunkan glukoneogenesis. Ketika kerja asetilkolin terganggu, maka pelepasan insulin ke darah terganggu dan jumlah insulin yang dilepaskan ke darah tidak mencukupi. Akibatnya, glukosa tidak dapat terdistribusi dengan baik ke otot dan hati karena jumlah insulin sebagai zat pengangkutnya tidak mencukupi. Hal ini berdampak pada terganggunya keseimbangan kadar gula dalam darah dan inilah yang menyebabkan kadar glukosa di dalam darah tinggi.

Hasil penelitian Perveen (2012) selain neurotoksisitas dan stres oksidatif, perubahan homeostasis glukosa sebagai puncak hiperglikemi merupakan karakteristik dari toksisitas organosfosfat. Pada penelitian yang diujicobakan pada binatang ditemukan bahwa organofosfat menghambat asetilkolinesterase dan menyebabkan akumulasi organofosfat, serta mengurangi produksi insulin (Van Koppen and Bjorn, 2003).

Berdasarkan hasil wawancara dengan responden, diketahui bahwa sebagian besar responden menggunakan pestisida organofosfat dan herbisida. Paparan jangka panjang dari penggunaan pestisida tertentu, khususnya organoklorin dan insektisida organofosfat berhubungan dengan meningkatnya risiko diabetes (Montgomery et.al., 2008). Beberapa jenis pestisida golongan organofosfat dan golongan organoklorin berhubungan positif dengan kejadian diabetes (Starling et.al., 2014). Hectors et.al (2011) juga menyatakan bahwa beberapa bahan pencemar lingkungan seperti senyawa organofosfat mempengaruhi fungsi sel beta pankreas secara penelitian eksperimental dan epidemiologi. Senyawa spesifik organofosfat yang berhubungan positif dengan diabetes adalah Chlorpyrifos, dictrotophos, dichlorvos, EPN (ethyl-p-nitrophenyl), mevinphos, monocrotophos, dan methamidophos (Juntarawijit and Yuwayong, 2018).

\section{Kesimpulan}

Kesimpulan penelitian ini adalah lama penyemprotan memiliki hubungan dengan diabetes mellitus pada petani di Desa Juhar Ginting Sadanioga Kabupaten Karo. Saran penelitian ini adalah bagi petani yang memiliki berat badan berlebih diharapkan untuk mengontrol berat badan dan bagi petani yang memiliki indeks massa tubuh normal untuk tetap mempertahankan berat badan. Selain itu, kepada para petani diharapkan untuk melakukan penyemprotan tidak lebih dari 3 jam per hari untuk meminimalisir risiko keracunan dan diabetes mellitus.

\section{REFERENSI}


Adnan, M., Tatik, M., Joko, T.I., 2013. Hubungan Indeks Massa Tubuh (IMT) Dengan Kadar Gula Darah Penderita Diabetes Mellitus (DM) Tipe 2 Rawat Jalan Di Rs Tugurejo Semarang. Jurnal Gizi Universitas Muhammadiyah Semarang, 2(1): 18-24.

Al-Othman, A.A.A., Sherif, H.A., \& Nasser, M.A., 2015. DDT and Its Metabolites are Linked to Increased Risk of Type 2 Diabetes among Saudi Adults: A Cross-Sectional Study. Environ Sci Pollut Res, 22:379-386.

Bays, H.E., Chapman, R.H., Grandy, S., 2007. The Relationship of Body Mass Index to

Diabetes Mellitus, Hypertension, and Dyslipidaemia: Comparison of Data from Two National Surveys. Int J Clin Pract: 61(5): 737-747.

D'adamo, P.J., 2008. Diet Sehat Diabetes sesuai Golongan Darah. Yogyakarta: Delapratasa. Hectors, T.M.L., Vanparys, C., Van der Ven, K., Martens, G.A., Jorens, P.G., Van Gaal, L.F., Covaci, A., De Coen, W., Blust, R., 2011. Environmental Pollutants and Type 2 Diabetes: A Review of Mechanisms That Can Disrupt Beta Cell Function. Diabetologi, 54: 1273-1290.

Hodgson, E. 2004. A Textbook of Modern Toxicology. Third Edition. New Jersey: John Wiley and Sons, Inc.

Hu, G., Jaana, L., Timo,T .V., Johan, G.E., Pekka, J., Karri, S., Qing, Q., Jaakko, T., 2004. Physical Activity, Body Mass Index, and Risk of Type 2 Diabetes in Patients with Normal or Impaired Glucose Regulation. Arch Intern Med, 164 (26): 892-896.

Juntarawijit, C., Yuwayong, J., 2018. Association between Diabetes and Pesticide: A CaseControl Study among Thai Farmers. Environ Health Prev Med. Biomed Central, 23(3): $1-10$.

Kementerian Pertanian RI. 2007. Peraturan Menteri Pertanian No.07/Permentan/SR.140/2007 tentang Syarat dan Tatacara Pendaftaran Pestisida.

Kementerian Kesehatan RI. 2013. Riset Kesehatan Dasar. Jakarta.

Montgomery, M.P., Kamel, F., Saldana, T.M., Alavanja, M.C.R., Sandler, D.P., 2008. Incident Diabetes and Pesticide Exposure among Licensed Pesticide Applicators: Agicultural Health Study 1993-2003. Amer J Epidemol, 167: 1235-46.

Mostafalou, S., M.A. Eghbal., A. Nili-Ahmadabadi, M. Baeeri., aand M. Abdollahi., 2011. Biochemical Evidence on The Potential Role of Organophosphates in Hepatic Glucose Metabolism Toward Insulin Resistance Through Inflammatory Signaling and Free Radical Pathways. Toxicol.Ind.Health, In Press.

Mostafalou, S., Mohammad, A., 2012. The Role of Environmental Pollution of Pesticides in Human Diabetes. International Journal Pharmacology, 8(2): 139-140.

Perveen, F., 2012. Insecticides - Pest Engineering. Rijeka: Intech.

Rahimi, R., Mohammad, A., 2007. A Review on The Mechanisms Involved in Hyperglycemia Induced by Organophosphorus Pesticides. ELSEVIER, 88(2): 115-121. Saputri, E.G., Onny, S., Nikie, A.Y.D., Budiyono., 2018. Hubungan Riwayat Pajanan Pestisida Dengan Kejadian Diabetes Melitus Tipe 2 Pada Petani Penyemprot Di Kecamatan Ngablak Kabupaten Magelang. Jurnal Kesehatan Masyarakat, 6(1): 645-654. 
Starling, A.P., David, M.U., Freya, K., S, L., Dale, P. S., Jane, A.H., 2014. Pesticide Use And Incident Diabetes Among Wives Of Farmers In The Agricultural Health Study. BMJ Journal: Ocuppational Environmental Medicine, 71: 629-635.

Trisnawati, S.K., dan Soedijono, S., 2013. Faktor Risiko Kejadian Diabetes Melitus Tipe II

Di Puskesmas Kecamatan Cengkareng Jakarta Barat Tahun 2012. Jurnal Ilmiah Kesehatan, 5(1): 6-11.

Turner. C.D., Joseph, T.B., 1988. Endokrinologi Umum. Yogyakarta: Airlangga University Press.

Van Koppen, C.J., Bjorn, K., 2003. Regulation of Muscarinic Acetylcholine Reseptor Signaling. Pharmacol Ther, 98(2): 197-220.

World Health Organization. 2017. Diabetes Mellitus. Jeneva. 